\title{
Article
}

\section{The Contrasting Soundscapes of Hull and London in David Bowie's Ziggy Stardust and the Spiders from Mars}

\author{
Atkinson, Peter James \\ Available at http://clok.uclan.ac.uk/16472/ \\ Atkinson, Peter James ORCID: 0000-0002-8638-9808 (2017) The Contrasting \\ Soundscapes of Hull and London in David Bowie's Ziggy Stardust and the \\ Spiders from Mars. Popular Music History, 10 (1). pp. 46-61. ISSN 1740-7133
}

It is advisable to refer to the publisher's version if you intend to cite from the work. http://dx.doi.org/10.1558/pomh.32555

For more information about UCLan's research in this area go to http://www.uclan.ac.uk/researchgroups/ and search for < name of research Group>.

For information about Research generally at UCLan please go to http://www.uclan.ac.uk/research/

All outputs in CLoK are protected by Intellectual Property Rights law, including Copyright law. Copyright, IPR and Moral Rights for the works on this site are retained by the individual authors and/or other copyright owners. Terms and conditions for use of this material are defined in the policies page. 


\title{
The Contrasting Soundscapes of Hull and London in David Bowie's Ziggy Stardust and the Spiders from Mars.
}

Peter Atkinson

\begin{abstract}
In this article I apply the concept of the urban soundscape as developed by Long and Collins (2012) in an analysis of the impact musicians from Hull had on the evolution of David Bowie's seminal 1972 work The Rise and Fall of Ziggy Stardust and the Spiders from Mars. I argue that the performance of Ziggy Stardust, both on record and on stage, is doubly coded in relation to place and space. The 'concept' of The Rise and Fall of Ziggy Stardust as a musical, a fictional story with songs performed on stage, and an accompanying album of recorded songs, initially appears to be heavily associated with London. The format of the concept which the creator described as theatre, rather than a rock and roll show - is derived from Bowie's experience growing up in London from the late 1940s to the early 1970s, a time of great change in the capital. I suggest that the Ziggy Stardust performance, and its significance, rests on the authenticity of the supporting musicians in the project, musicians from Hull, Yorkshire, with whom Bowie had been playing for more than two years before it was aired. I illustrate that Bowie and his support cast were subject to different cultural settings, and thus influenced by different soundscapes, and the relevant properties from each are compared here. I go on to provide some assessment of how the involvement of these Hull musicians in the Bowie project has impacted upon the city's historical music culture, and on heritage issues and cultural production in that town. I conclude by noting that Hull has a thriving arts community and is UK Capital of Culture in 2017.
\end{abstract}

\section{Keywords}

David Bowie 
Ziggy Stardust

Soundscape

Mick Ronson

Hull

London

Heritage

UK Capital of Culture 2017

Dr Peter Atkinson is Senior Lecturer in Film and Media at University of Central Lancashire, specializing in popular music and television in the North. Peter has published on the role of broadcasting in the creation of the Beatles and Mersey Beat myth of the early 1960s and on the topic of Abbey Road Studio, tourism and Beatles Heritage. Most recently he has published a book chapter on the influence of the 1930s agit-prop theatre and radio documentary work of Ewan MacColl on the 1980s Manchester aesthetic of The Smiths and on the topic of ITV soap opera and representation of northern England.

Dr Peter Atkinson, School of Humanities and Social Sciences, University of Central Lancashire, PRESTON, PR1 2HE. E-mail: pjatkinson1@uclan.ac.uk

\section{Soundscape and Place}

Long and Collins use the term 'soundscape' to refer to 'the relationship of music, space and heritage' (Long and Collins 2012: 145). Their work follows theoretical approaches to the examination of soundscapes undertaken by the likes of Murray Schafer (1994 [1977]) and Thompson (2004). Thompson defines the soundscape as 'an auditory and aural landscape' which is 'simultaneously a physical environment and a way of perceiving that environment' (Thompson 2004: 1). Physical aspects of a soundscape consist not only of the sounds 
themselves, she notes, but also the material objects that create, and which can sometimes destroy, these (Thompson 2004: 1). To this we can add that there may be an evolution of the soundscape which is derived from both the development of material objects, the creative use of these objects, the social uses of this creative production, and the subsequent cultural outcomes of all these things within culture. An example of this may be found in a town ballroom, used in the 1930s and 1940s for dancing to the tunes of live dance bands featuring brass and / or string instruments. The premises may have adapted in the late 1950s and 1960s and staged rock and roll, or pop, events which featured amplified electric guitar and vocals. The same buildings in the 1970s may have been converted into other uses, such as disco, where the music played was loudly amplified records. Thus, there is an evolution of the local soundscape. A cultural outcome in this case is that those people at the discotheque are not listening to live music, but to recorded product - music from another place, quite possibly another country. This has consequences in relation the listener's sense of belonging to the place where s/he hears the music. As Thompson states,

A soundscape's cultural aspects incorporate scientific, and aesthetic ways of listening, a listener's relationship to their environment, and the social circumstances that dictate who gets to hear what. A soundscape, like a landscape, ultimately has more to do with civilization than with nature, and as such, it is constantly under construction and always undergoing change. (Thompson 2012:

Developing Thompson's theory, Long and Collins (2012: 146) conclude that, 
Sound ... is to be accounted for not only as a matter of what we hear, but also as those practices that produce, use and make sense of it. This framework offers a suggestive means of making sense of the role of music in and about the city, of musical cultures and encounters with a polyphony of tunes (and other noises), of how they are heard and the meanings they have for creators, consumers and those who would avoid or ignore them, amplify, mute, commodify, preserve or indeed recall and map them as an aspect of experience.

Long and Collins's use of the concept of soundscapes is to map 'historical music cultures' (Long and Collins 2012: 145). Summarising Whiteley's analysis of the relationship between music and place, they note that the interweaving of music and space has a role in the construction of national identity, the interrelationship of the local and global and 'the formation of the cultural industries that produce and circulate commodities and meanings.' In this way, the soundscape of popular music 'has a role to play in the branding and selling of place' (Long and Collins 2012: 146). Ziggy Stardust was shaped by an interaction between two distinct soundscapes: metropolitan London, and provincial Hull. I analyse the relationship between the two soundscapes here in terms of the discourses that derive from the juxtaposition of the two. Long and Collins analyse the mapping of the Birmingham soundscape in the Birmingham Popular Music Archive. They consider the dissemination of information in and from that project and assess the cultural uses that derive from this. I provide some analysis here of how the Hull soundscape impacts on heritage issues in that town and on cultural production there. Soundscape is always assessed retrospectively, a particular moment in sound is always already gone. And assessment of a soundscape is a discursive activity, whereby meaning is assigned to particular arrangements of sound for the purpose of conducting analysis, usually of socio-cultural circumstances and / or phenomena. I 
now compare the soundscapes of London and Hull and assess their influence on the practitioners who created Ziggy Stardust.

A lost clip of David Bowie performing his single 'Jean Genie' on Top of the Pops on 4 January 1973 was quite recently unearthed. The performance is not only notable because it remained inaccessible for more than forty years, but also because in it, the band is playing live (although the programme was recorded the day before). This is unusual for Top of the Pops and the clip provides a useful record of the band's musical style at the time. In it Bowie, dressed glam, plays the fictitious Ziggy Stardust, the character role he performed in 1972 and 1973 before killing it off in that year. He fronts the nominally fictitious backing band The Spiders from Mars who, in reality, are all from Hull. 'The Spiders' chug away delivering this Bo Diddley-inspired number, their rhythm and blues sound a derivation of electric Chicago blues to which Bowie also contributes blues harmonica. ${ }^{1}$ At one point in the Top of the Pops clip, Bowie includes the harmonica melody line from The Beatles' first single, 'Love Me Do' and it is notable that The Beatles were engaged to play The Majestic Ballroom in Hull at the time of that record's release - October 1962 - not because they were famous (the record had only been a minor hit), but because the venue needed a group to attract an audience for its Bingo. The inclusion of a reference to the first Beatles record, a formative influence in English pop music, is self-conscious and knowing on Bowie's behalf as, indeed, is his entire performance. Ziggy Stardust was, precisely, a knowing post-modern manipulation of the conventions of the process of stardom. But Bowie's interpretation was one transferred

\footnotetext{
${ }^{1}$ My thanks to Leslie Gillon for pointing out that the Hull musicians, although from a different geographical area, may have experienced some of the same media dissemination of music as Bowie in London. For example, radio, and pirate radio, were influential in promoting particular music forms, this affecting local soundscapes.
} 
wholesale to the rock genre which had developed a strong ideological dimension since the mid-1960s as it became the common currency of a so-called cultural revolution and a vehicle for the expression of the views of the counter-culture.

\section{David Bowie, the Suburban London boy}

The success of Ziggy was the culmination of the artist's years spent absorbing the sounds and the culture that England's capital had to offer. David Jones was born in Brixton, south London, in 1947 and his career was shaped by his experience growing up in suburban Beckenham and Bromley. The youngster followed the well-trodden path of finding escape, fulfilment and new career prospects, in the town centre. Doggett writes that, as a teenager, Bowie 'emerged in 1963 in the planet's most vibrant city' ready to witness - and be a part of - the 'brief flowering of freedom and creativity' of what has become mythologized as 'the sixties' (Doggett 2012: 17). Bowie hung around the fashionable areas and was introduced to the bohemia of Soho and to jazz clubs by his brother Terry, who later suffered from mental illness. He was in a band, The Kon-Rads by the time he was fifteen and, after seeing the Rolling Stones on the Bo Diddley tour of 1963 and getting hooked on rhythm and blues, formed The King Bees, the name deriving from the Stones's cover of a 1957 Slim Harpo blues song, 'I'm a King Bee', a popular number covered live or on record by numerous other British groups. Bowie at the time had a lowly post at an advertising agency but prospects were good and the job taught him the art of self-promotion, which he used to sell himself and the group to a minor imprint of Decca Records, Vocalion. Proximity to the industry in the capital creates opportunity and inspires a confidence perhaps lacking in the provinces. Bowie was in a string of other London groups: The Mannish Boys (who supported The Kinks on tour), The Lower Third and The Buzz. He adopted the stage name 'David Bowie' in 1965 to 
avoid being confused with other artists that shared his real name. Bowie identified strongly with the Mods in the fashion-conscious cauldron of pop London, with its vibrant new music scene which produced one of the most distinctive soundscapes in the history of music. This was a city that spawned a host of bands and artists who became internationally renowned and have provided an enduring legacy: The Rolling Stones, Pink Floyd, The Who, The Kinks, The Small Faces, Elton John, Eric Clapton, Jimmy Page, Rod Stewart and Jeff Beck. In addition to this, the scene also produced a host of artists who attracted, and continue to attract, a cult following: The Yardbirds, Julie Driscoll, The Pretty Things, Arthur Brown, The Action. The soundscape and culture permeated Bowie's consciousness, inspiring him to write and he produced the harrowing 'slice of Soho life' song 'The London Boys' in 1965 (Doggett 2011: 36).

Frith (2007: 139) claims Bowie is the 'quintessential suburban star.' The suburbanite, he suggests, may map her/his 'obsessions and alliances' onto the city streets of places such as Soho in an 'enactment of escape'. This in effect happened when Bowie's disciples, the socalled New Romantics, descended upon Soho at the beginning of the 1980s, setting up a series of club nights with a cult following in clubs such as Blitz, Billy's and The Wag. For Frith, this is effectively a 'suburbanization of the city' (Frith 2007: 140). Suburban culture is predominantly white, middle class and 'white south-eastern English culture', he notes, and continues that the term describes,

An urban phenomenon, the dominance of London, the concentrated site of both political and cultural power. The sub-urban sensibility ... is sub-London 
sensibility. From this media perspective other English cities (and even Scottish, Northern Irish and Welsh cities) are themselves effectively suburban.

Frith concludes with a specific reference to perceived subordinate status of the north in relation to this London hegemony, observing that the point about [Manchester Britpop band] Oasis, and The Beatles 'is not that they are ... from the north, but that they are seen and heard' by the south, to be 'northern' (Frith 2007: 138). It may thus be seen how, in light of this argument, a significant and culturally important work produced by an association between the suburban Bowie, and a group of musicians homogenized by their common roots in the northern town of Hull, is discursively double-coded. The meaning of Ziggy Stardust can only be interpreted with references to the two, distinct, places. The essence of the difference between the two soundscapes is economic - wealthy metropolitan London both imported and produced much music, and was culturally diverse; whereas the provision of music in the less wealthy, provincial Hull was more limited, and the town less diverse. London had the elaborated soundscape, Hull had a soundscape that was secondary to this, one subject to the former's influence.

Returning to the narrative of Bowie's evolution as a musician, the singer was introduced to London's wider social and cultural influences, as well as literary influences, by Kenneth Pitt, who became part of his management in 1966. Pitt was agent for acts such as Manfred Mann and Bob Dylan, but had also acted for London all-round entertainer, Anthony Newley whom Bowie idolised. Alongside his work in musicals, on stage, film and television, Newley had released some novelty singles (such as a version of the music hall classic 'Pop Goes the Weasel') in which he adopted an 'exaggerated London barrow-boy' cockney accent (Doggett 
2011:12: 39). Bowie copied this affected vocal style for some of his songs. He produced the Deram LP David Bowie (1967) which failed to establish him as a name artist (the LP was released on the same day as The Beatles' Sergeant Pepper's Lonely Hearts Club Band). The LP has subsequently been associated with music hall, with its short story-like cameos and observations of the quirkiness of English, and London, life. The work was widely derided especially for such items as the song 'The Laughing Gnome' - but Pegg observes that these cameos are consistent with the work of Pink Floyd's Syd Barrett and also The Beatles at the time. The Kinks must be added to this list and Pegg notes that these music hall-like Bowie songs were also an influence on quirky novelty act, The Bonzo Dog Doo-Dah Band, (Pegg 2011: 295). David Bowie is an example of what Cloonan, and others, have labelled 'Pop Englishness', and is a part of that canon of work (Cloonan 1997; Bennett and Stratton 2010).

By 1968 Bowie's own interests were divergent, and he was encouraged by his proximity to London's arts and cultural production and to the country's major media providers. He wrote a radio play, a musical, planned a TV documentary, aimed to become a cabaret star, worked with mime artist Lindsay Kemp and, finally, got into folk in that year. He worked with several permutations of acoustic folk bands - Turquoise, Feathers - and in a duo with Yorkshireman John Hutchinson. He also participated fully in the counter-cultural milieu and was a co-founder of the Beckenham Arts Lab. However, he became disillusioned with the ideology of the counter-culture. His disenchantment coincided with an ebbing away of sixties utopianism, this being the result of several factors: the end of The Beatles; the Stones' debacle at Altamont - the antithesis of Woodstock 'love and peace'; the student riots; and the sharp downturn in the economy. Elsewhere, Syd Barrett, of whom Bowie was a fan, had been eased out of the hip Pink Floyd because of his erratic, drug-induced behaviour. 


\section{Hunky Dory, with Hull Help}

Bowie's next project was to record for his new label Mercury and, having been turned down by The Beatles producer George Martin, he was to work with American music producer Tony Visconti. A song 'Space Oddity' had been identified as a first single, which Visconti did not like and thus Gus Dudgeon produced the song which capitalized on the contemporary public interest in the moon landing of that year. When 'Space Oddity' became a surprise hit and Bowie quickly needed a backing band to record more material and promote it, Junior's Eyes were commissioned, who featured Hull musicians, guitarist Mick Wayne and drummer John Cambridge. Their album, Battersea Power Station (1969) was produced by Visconti (who also produced Bowie's friend Marc Bolan with his acoustic folk duo Tyrannosaurus Rex and the later electric rock version of the same band, T Rex). After confusingly releasing a second LP titled Bowie (1969), so named to build the brand name, Bowie formed The Hype so that he could tour his new work. This featured Visconti on bass and Cambridge on drums who, after singing the praises of Hull guitarist Mick Ronson, travelled there to persuade the guitarist to join. Ronson had recently played guitar on an LP by a Hull folk musician, Michael Chapman, the album being produced by Dudgeon who had been impressed with Ronson's contribution. The Hull guitarist performed with Bowie on the John Peel Sunday Show on 5 February 1970 and from this point until 1973, the Hull guitarist played a prominent role in the production and performance of Bowie's music, as would other musicians from the northern town.

From the Peel appearance, Ronson is credited with having contributed his 'muscular' guitar 'power chords' to the song 'Width of a Circle', then in embryonic form, but which appeared on Bowie's new LP The Man Who Sold the World (Mercury Records 1970) (Weird and Gilly 
2012: 45). Cambridge was sacked from the band after performing poorly and returned to Hull to be replaced by 'Woody' Woodmansey, also from Hull, who had played in Hull band The Rats with Ronson. For the recording sessions that eventually produced the songs for The Man Who Sold the World the musicians were largely left to create the music themselves as Bowie's input during the production of the musical element was minimal. He would come into the studio, present them with little more than some chord sequences, and then leave (Weird and Gilly 2012: 50). Woodmansey recalls that the band put the tracks down with guitar, bass and drums, with no idea what song would be put on top. He refers to the Hull soundscape, saying that he and Ronson had 'just come out of this hard rock area' - that was what 'we were influenced by'. Bowie, by contrast, 'had never touched' that musical area and Woodmansey indicates that Visconti had not either (qtd. Weird and Gilly: 51). What resulted was a dark LP of heavy rock, totally distinguished from Bowie's former acoustic aesthetic, and the melody of the second David Bowie LP. The title of the song 'Black Country Rock' on The Man Who Sold the World references a regional variation in soundscape. The singer felt that the music sounded like that of The Move, who were from Birmingham, in the Midlands region of England and 'spontaneously' gave the music that title, before he had written lyrics for it. The Midlands includes a district known as the Black Country because of its heavy industrial environment (Doggett 2012: 91). This is significant in the chronology of Bowie's development as an artist, and in relation to impact of regional soundscapes upon popular music. 1970 was also the year of release of Black Sabbath's eponymous first LP, and a year in which there was a discernible shift in the rock genre. Cope (2013: 4) argues that Heavy Metal began with Black Sabbath in Birmingham in the 1960s. He suggests that, and gives examples of how, the austere, working-class industrial environment of noisy factories and limited opportunity for upward social mobility, impacted upon the production of rock music there (Cope 2013: 26). There is a similarity here with the way in which the soundscape of 
Hull influenced Bowie's music, giving the former folk artist a 'heavy' sound, derived from an environment of lesser economic and cultural expectation than London.

Ronson and Woodmansey were invited back to London to work on Bowie's next album, Hunky Dory. Celebrated keyboard player Rick Wakeman was also asked to join the band but declined because of commitments. This may have been significant as Wakeman had a high profile as a musician and possibly would have influenced Bowie to take a different musical direction than the one he did with the Hull musicians. Ronson's own classical training in piano and violin meanwhile enabled him to do arrangements for some of the songs on this LP, including lauded productions such as 'Life on Mars'. 'Queen Bitch' meanwhile points forward to the rockier numbers on Ziggy Stardust, Ronson's power chords a raunchy diversion from the sweet melodies, piano and acoustic guitar prominent on the rest of the LP. Woodmansey concludes that,

Hunky Dory is a bit too 'songwriter-like'. The eventual sound that we ended up with on Ziggy Stardust had more of a group sound. Although it was still David Bowie, it was more of a group thing. That's really what he needed. Mick [Ronson] was instrumental in much of that because he was able to take Bowie's chord sequences and put it into a rock thing. (qtd. Weird and Gilly 2012: 65)

Woodmansey's comments confirm the nature of the contribution the Hull musicians made to the project. Their integration into the visual and ideological aspects of the spectacle proved more problematic however, as differences became apparent between the approach and stance of the suburban London boy, and the lads from the small northern town, as will be discussed 
later. Firstly, it is necessary to consider the properties of the Hull soundscape that influenced these musicians.

\section{The Hull Soundscape}

Hull in effect mirrors Liverpool on the west side of northern England. Like that port, the east coast town of Hull is built on an estuary, the Humber - which faces the North Sea and Europe, as opposed to the Mersey, which faces the Atlantic and Ireland and America. This caused Liverpool to be greatly affected by Celtic migration and shipping links with America, these factors influencing the development of the distinctive music scene and character that was so influential in 1963-64. Hull was not affected by such port links and yet suffered from a similar decline to Liverpool in the 1920s and 1930s. This, the Hull History Centre website notes, was 'exacerbated by overproduction in the fishing industry.' During World War II Hull was the heaviest bombed city outside London, this necessitating considerable post-war reconstruction. The profile the town's trade meanwhile changed after the War, the smaller and older docks being closed while the Queen Elizabeth Dock opened in 1969 to handle container traffic. Hull continues to thrive servicing large ships and providing a ready link with Europe (www.hullhistorycentre.org.uk).

The Hull soundscape in the 1960s and early 1970s did not have the elaborated character of London's, nor the cocky energy of Liverpool's beat scene. London was still the home of the UK entertainments industry, despite the challenge of The Beatles and the Mersey Beat groups in 1963-64. The Beatles moved to London immediately when they first achieved fame. Hull was not yet linked directly by motorway to London and a train journey between them would take some five hours. Here, local provision of music co-existed with music provided by the 
London industry. Local music venues booked both local acts, and touring acts. Thus, groups such as The Beatles and Rolling Stones and many others visited the area in the early-to-mid 1960s, and were in some cases supported by local groups. Ronson's first gig was with The Mariners, supporting the Stones at Bridlington in 1963. The Spa Hall in Bridlington, a few miles from Hull, held all-nighters in the early-to-mid 1960s. An event on 14 February 1964 is advertised as being between 20.00 and 06.30 , with late bars until 03.00; early breakfasts from 03.30. Top of the bill of the eleven bands performing was (what is wrongly claimed to be) 'the Merseysound' of Tony Sheridan and the Sundowners (although there was a Hamburg connection between Sheridan and The Beatles). One of the support groups was Dean Webb and the Spidermen, the event, as with others at the time, thus featured a mixture of a national touring acts, and local bands. Tully's ballroom in Market Place, Hull meanwhile had Rock Night every Saturday, with 'Hull's top groups' and in the same period jazz was popular in Hull clubs. Most of the local bands played cover versions of songs by nationally known British and American artists. The bill of the Skyline Ballroom featured a mixed-usage provision referred to earlier, with ballroom dancing on some evenings, but featuring rock'n'roll on Thursdays in 1963. The same venue held rock'n'roll and pop singing competitions around the same time as Beatlemania newly enthused the nation's aspiring musicians. Later, the same venue would host The Small Faces, The Kinks, Cream, Pink Floyd and Jimi Hendrix who was, Palmer notes (2012), supported by a host of local bands. Hull also had a well-established folk scene - as, indeed, did London. The publicity for the Hull Folk and Maritime Festival in 2016 stated that,

Hull has a strong folk tradition; its status as a major port over the centuries meant that ideas and influences from different cultures and nationalities have been readily assimilated, adding to the diversity and richness of those traditions, while the city played an important part in the post-war folk revival, with the 
establishment of The Folk Union One Club above Ye Old Blue Bell pub in 1963 by The Watersons, who would go on to forge one of the most influential family dynasties in British folk music. (www.hull2017.co.uk)

Meanwhile The Who's performance at Hull University in 1968 is the stuff of local legend; local attendee Mike Lawton tartly notes however that it was their performance at Leeds University which was committed to record in that year (The Who, Live at Leeds) and not the one at Hull. The local scene, and thus its soundscape, was plainly affected by the hegemony of the London-based entertainment industry and, in national terms, was secondary to it. The documentary DVD Hot Coca-Cola with a Slice of Lemon (2012) has been enthusiastically produced by Hull Museums and Heritage Volunteers with an accompanying leaflet by Alan Palmer. The title is a reference to a popular drink served in the Gondola club, which staged live rock and pop in the 1960s, but which did not have a licence to sell alcohol. Ronson and the rest of the Spiders are the most prominent local musicians featured in the booklet but it also references other local acts from the period including Michael Chapman, The Hullabaloos (who enjoyed success in the USA as a part of the 'British invasion'), The Aces, The Small Four and the girl-group Mandy and the Girlfriends.

\section{'Then we were Ziggy's Band'}

By the time Bowie and band began recording songs that would eventually be included in Ziggy Stardust, they had been joined by another Hull musician, Trevor Bolder. Bolder had played in Ronson's short-lived project, his band Ronno, in Hull. Meanwhile Bowie's idea of creating a fictitious character came from the short-lived 1971 Arnold Corns project. This was 
his attempt to con the audience by creating a star, Corns - who in reality was his fashion designer friend Freddie Burretti - who did not actually sing on his own records, which would be performed by Bowie himself. The scheme undermined the 'hippie ideology' of authenticity that underpinned the relationship between rock musicians and their audience by the late 1960s, Auslander argues (2006: 132).

Bowie associated himself with what was termed 'underground music' in the London of the late 1960s. This was characterised by progressive development of technique, experimentation, movements towards cross-fertilization of genres, increased investment in the ideological meaning and significance of music, and an increasing political role for music. Popular music was the lifeblood of the so-called counter-culture, something Bowie was acutely aware of indulging in its activities, but eventually rejecting its ideology. The latter was facilitated by exposing the inherent theatricality of the very performative nature of rock stardom with his Ziggy Stardust creation. This began to take shape in autumn 1971 with recording of songs for the album. By early 1972, as recording continued, the look of the performance was also coming together as Bowie cropped his long hair to the famous spiked and dyed look and began performing in space-age attire. Woodmansey notes meanwhile that 'the pace of recording [the songs] was unprecedented' (Pegg 2011: 318). Bowie and the band would enter the studio and record songs one day, listen to them back, then record the final version the next. This suggests that Bowie and his band were a tight and integrated little unit by this time - actually an authentic rock band, the significance of which is discussed below.

The successful union of an authentic, homogenous band, and the conceptual creation of fictitious persona derive from two soundscapes being juxtaposed in the dressy Ziggy project: those of Hull and London. Stereotypical north / south binaries are evident in the discourses 
that derive from the contribution of the Hull musicians as examined below, yet their provinciality was the taut canvas upon which the metropolitan Bowie painted his glitzy fiction. Writing of the Ziggy era, Waldrep concludes that Bowie's presentation of self is futuristic, a utopian project that 'does not have an actual origin.' It is a performance of gender and/or sexuality that is a simulacrum' (Waldrep 2015: 29-30).

Bowie had announced himself to be gay in January 1972 but Ronson had forcefully rejected the singer's request that he too should 'pretend' to be gay and to announce that they were in a bi-sexual affair, his wife Suzi Ronson has recalled (qtd. in Weird and Gilly 2009: 67). However, the Hull Spider Ronson participated significantly in the performance of queer identity in the Ziggy Stardust stage show. In footage of the concerts he struts the mid stage area, at once evidently tied to his working band slightly behind him and to his right, their unity displayed in looks exchanged between the members as Ronson drives the music. He periodically joins Bowie at the microphone to share vocals (as illustrated in Bowie and Rock 2005). This produced iconic images which echoed those of The Beatles, and of the Rolling Stones' Jagger and Richards who similarly shared a microphones whilst looking straight at one another face-to-face. Such images were always dually coded as signs of homosocial comradeship, but also with homoerotic connotations. Famously, Bowie would perform mock fellatio on Ronson's guitar during his soaring solo on 'Moonage Daydream' (which was the original Arnold Corns single, but included in Ziggy Stardust in altered form).

Waldrep asserts that the central tenets of Ziggy Stardust are 'queerness, Orientalization and futurity' (Waldrep 2015: 30). The Spiders, whilst not conforming to the exotic image the main character of the show presented, nonetheless delivered raunchy rock'n'roll for an early seventies audience disaffected by the middle class hippy ethos and the counter-culture of the 
1960s. The costumed, space-thing performed by Bowie bawls out the American slang phrase 'Ahhhhh, wham, bam, thank you ma'am' as the band belts 'Suffragette City' to a climax. It is a misogynistic rock and roll past meeting an androgynous future in a cathartic rock spectacle that highlights the very artificiality and pretence of its own delivery. The essence of the Ziggy Stardust project and its meaning is a double coding of 'alterity' (embodied in the metropolitan suburbanite Bowie's performance) and authenticity (embodied in that of the northern, provincial band) (Auslander 2006: 132). This enabled a high art statement to be suggested in what was really just another rock show. Such ambiguity pointed forward to the commoditized future of the enterprise culture of the 1980s and beyond, as is examined below.

\section{From Counter-Culture to Commodification}

Taylor and Wall (1976: 115) note that underground artists who expressed the sentiments and ideology of the 1960s counter-culture, 'stressed an intellectual commitment to their music' and frequently eschewed 'direct influence from commercialism'. Part of Bowie's art in creating himself a star with Ziggy was for his management, MainMan, to treat him, 'the product', as a star 'even if nobody knew he was yet', Taylor and Wall observe (1976: 116). Although Bowie's figure of alterity raised ideological questions relating to gender, sexuality and the nature of performance, this was achieved mainly through processes that involve consumption: discipline of the body in trained dance and physical fitness; extravagant clothing and fashion; cosmetics and styling; and the visible trappings of stardom (an opulent celebrity lifestyle, publicized by press and media). The art of Ziggy Stardust was a prefiguration of the consumerist, fashion-obsessed, celebrity-centric, 'makeover' culture of today. Taylor and Wall (1976: 116) note that Bowie fused the commercial form of Glam Rock with the content of underground music (the music strongly associated with the counterculture) but sharply conclude that, 
Bowie ... colluded in consumer capitalism's attempt to re-create a dependent adolescent class, involved as passive teenage consumers in the purchase of leisure prior to the assumption of 'adulthood', rather than being a youth culture of persons who question ... the value and meaning of adolescence and the transition to the adult world of work. (Taylor and Wall 1976: 117)

The Hull musicians were complicit, although unwittingly, with the project, permitting a ready address to a working class audience through their association with myths of the north, northern working class resilience and openness, but also sexual conservatism. Yet, the connotations of their working class northern presence permitted an identification with the Ziggy Stardust project by an audience who may have been otherwise alienated by the work had the supporting musicians been recruited from the middle class and, like Bowie, been from southern England.

Ziggy Stardust pointed forward to the post-industrial society in which the industrial economy of manufacture was (forcibly) replaced by a service economy of lifestyle consumption. Martin Roth, Director of the Victoria and Albert Museum writes that,

One of his greatest impacts on our cultural life has been as a proponent of individualism - that we should be who we want to be, look how we want to look, and lead, not follow, without depending always on the views of others. (Roth 2013: 17) 
Yet Hewison notes that, in the movement to the free market, consumerist, enterprise society of the 1980s the freedom of the individual is 'purely economic' and,

The market becomes the only sphere of social action, and the economic becomes the only motive of morality. Ultimately, economic activity becomes the principal form of human expression. As the obsession with 'style' during the eighties shows ...- you are what you buy. (1997: 212)

In the eighties gender distinctions became less strictly defined in terms of dress and the performativity of traditional male and female roles. In this respect Bowie's performance of Ziggy Stardust is prescient. For Waldrep s/he 'seems to present an alternative to gender encoding as it might exist in the future'. He continues,

Bowie seems to imagine a universe in which sexuality is no longer a binary choice. To some extent, Bowie simply looks ahead to a more tolerant time, but it is not clear that he is queering straight identity so much as positing an identity that does not yet exist. His performance fractures gender and sexuality, but does not put them back together into a coherent whole. (Waldrep 2015: 30)

He concludes that, with Ziggy,

Bowie emphasizes the artificiality of all performances, including those of gender and sexuality. He realigns politics so that it is not just about electoral politics but identity politics as well. The personal becomes political in the seventies, and Bowie plays his part in making this fact known. (Waldrep 2015: 31)

In the work, David Bowie anticipated modern-day liberal attitudes and metropolitan lifestyles that circulate around modes of conspicuous consumption. Ziggy Stardust also anticipates the 
centrality of spectacle to modern culture, not only in music, but in many public spectacles: in festivals, carnival, parades and other specially formulated public events. His influence in this respect is such that the Victoria and Albert Museum created the spectacle of a five month exhibition exploring 'the broad range of Bowie's collaborations with artists and designers in the fields of fashion, sound, graphics, theatre, art and film' (Victoria and Albert Museum website). The exhibition later toured, there was a documentary film made around the exhibition, a lavish publication - David Bowie Is (from which the Roth quote above is extracted), and a range of merchandise made exclusively available. In the year of his death, forty four years after Ziggy Stardust, spectacles have been created across the globe in his honour. At Glastonbury 2016 his trademark Ziggy and Aladdin Sane lightning-flash logo topped the Pyramid Stage and many artists covered songs of his in tributes.

Yet in the period of his career that commonly held to be 'the most important historically,' his Ziggy representation, crucially, was grounded in the authenticity of the music provided by the backing musicians who were, collectively, from a small northern town (Waldrep 2015: 28). This unexceptional town could therefore be discursively interpreted as being a signifier of the genuine, a balancing counterpart to the fictionality of the Ziggy Stardust project which justified its relevance. The transgressive 'rise' of Ziggy Stardust and The Spiders from Mars is conceptually supported by the notion that this authentic band of provincial musicians from Hull are doing just that: rising to stardom under the leadership of the more cultured Bowie. It is notable that The Rats recorded a song 'The Rise and Fall of Bernie Gripplestone' in 1967. The northern name of the protagonist here is consistent with north's association with social realism in the first half of the decade and contrasts with the exotic nature of Bowie's derivation in the full name of the Ziggy album with its cosmic connotations. 


\section{Coda: Hull's Heritage and UK Capital of Culture 2017}

In later years a list of more recent music acts has been added in the continuing mapping of Hull's historical music culture, these being organically related to its soundscape. The likes of The Housemartins, Everything but the Girl, Red Guitars and Fila Brazillia are celebrated as having some origin in Hull and Palmer (2012) notes that there was a vibrant music scene in the city, as the Hull Music Archive confirms. There is an historically proud, parochial enthusiasm within the scene which is reflected in the town's aspirational culture programme. Forty five years on from Ziggy Stardust, Hull became UK Capital of Culture 2017, the second town to enjoy the status, the first being Derry-Londonderry in 2013. Fila Brizillia's Steve Cobby provided the soundtrack for the UK City of Culture 2017 bid film - 'This City Belongs to Everyone', this illustrating the importance of music to local culture and the democratic tone of the town's offer. Hull's cultural programme in 2016, the year leading up to City of Culture spectacle, included - as well as the Hull Folk and Maritime Festival - the Hull Jazz Festival which promised to bring 'the best in jazz, funk, soul, reggae and improvised music to venues across the city' (www.hull2017.co.uk). There was also Humber Street Sesh, the annual street festival including music which promotes and celebrates the excellence and diversity of Hull's creative community. The festival played a significant role in raising the city's cultural ambitions and the City of Culture bid. Hull's Freedom festival also featured music.

The City of Culture scheme was inspired by the success of Liverpool being named European Capital of Culture in 2008, an European Union initiative. This brought significant social and economic benefits to Liverpool, as well as demonstrating how well a cultural spectacle could be delivered in a city that had previously been blighted by a pronounced economic downturn. 
The organizers of Hull 2017 put 'the transformational power of culture' at the centre of their offer (Hull UK City of Culture 2017 website). They promised that the arts and cultural programme would 'celebrate the unique character of the city, its people, history and geography,' and that they would 'work with the artists of Hull and celebrate the culture of the city and its place in the wider cultural offer of the North, and make Hull a cultural destination for must-see events.' The website also talked of a Hull 'redefined within the Northern Powerhouse, but with a voice and confidence of a people on the up (Hull UK City of Culture 2017 website).' It has been demonstrated here that Mick Ronson and the other Hull musicians who contributed to Bowie's music 1969 to 1973 played a vital role in developing the city's musical heritage, and also in redefining of English music as two contrasting soundscapes merged in the creation of the seminal Ziggy Stardust production.

\section{References}

Auslander, Philip. 2006. Performing Glam Rock: Gender \& Theatricality in Popular Music. Ann Arbor: University of Michigan Press.

Bennett, Andy and Jon Stratton. 2010. Britpop and the English Music Tradition. Burlington: Ashgate.

Bowie, David and Mick Rock. 2005. Moonage Daydream: The Life and Times of Ziggy Stardust. London: Cassell Illustrated.

Cloonan, Martin. 1997. 'State of the Nation: "Englishness," Pop, and Politics in the mid1990s.' Popular Music and Society 21.2: 47-70.

Cope, Andrew L. 2013. Black Sabbath and the Rise of Heavy Metal Music. Farnham: Ashgate. 
Doggett, Peter. 2012. The Man Who Sold the World: David Bowie and the 1970s, London: Vintage Random House.

Frith, Simon. 2007. 'The Suburban Sensibility in British Rock and Pop'. In Taking Popular Music Seriously: Selected Essays, ed by Simon Frith, 137-147. Burlington: Ashgate.

Gibson, Paul. Hull and East Yorkshire History. www.paul-gibson.com [Accessed 30.06.16]. Hewison, Robert. 1997. Culture and Consensus: England, Art and Politics Since 1940, rev. edn. London: Methuen.

Hull Music Archive. www.hullmusicarchive.co.uk [Accessed 30.06.16].

Hull UK City of Culture. 2017. www.hull2017.co.uk [Accessed 24.06.16].

Long, Paul and Jez Collins. 2012. 'Mapping the Soundscapes of Popular Music Heritage'. In Mapping Cultures: Place, Practice, Performance, ed. Les Roberts, 144- 159. London: Palgrave Macmillan.

Palmer, Alan. 2012. Hot Coca-Cola With a Slice Of Lemon. DVD. Hull Museums and Heritage Volunteers.

Pegg, Nicholas. 2011. The Complete David Bowie, $6^{\text {th }}$ ed. London: Titan Books.

Mathie, Steve. 2010. The Famous Side of Hull. Hull: Riverside Publishing.

Murray Schafer, R. 1994. The Soundscape: Our Sonic Environment and the Tuning of the World. Rochester: Destiny Books.

Roth, Martin. 2013. 'David Bowie is What Follows'. In David Bowie Is, ed by Victoria Broakes and Geoffrey Marsh, 16-17. London: V\&A Publishing.

Taylor, Ian and Dave Wall. 1976. 'Beyond the Skinheads: Comments on the Emergence and Significance of the Glamrock Cult'. In Working class Youth Cultures, eds Geoff Mungham and Geoff Pearson, 105-123. London: Routledge and Kegan Paul.

Thompson, E. 2004. The Soundscape of Modernity: Architectural Acoustics and the Culture of Listening in America, 1900-1933. Cambridge MA: MIT Press. 
Victoria and Albert Museum. www.vam.ac.uk [Accessed 30.06.16].

Waldrep, Shelton. 2015. Future Nostalgia: Performing David Bowie. London: Bloomsbury Academic.

Weird and Gilly. (2009). Mick Ronson: The Spider with Platinum Hair. London: John Blake. 